\title{
Stylistic Gender Differences in the Literary Representation of Detective Talk
}

\author{
Elena Ortells and Santiago Posteguillo \\ Jaume I University
}

ortel@fil.uji.es / postegui@fil.uji.es

\begin{abstract}
Although substantial work has already been done on the variation between men and women in real speech, not so much has been carried out on the representation of speech in literature. The ample presence of dialogic interactions in the detective novel turns the genre into an extremely productive field of research in relation to represented conversation. In this paper, a corpus consisting of 79 one-to-one dialogues from eight different novels written by four well-known and best-selling authors is analysed according to six research questions. We believe it is the context, the pragmatic situation which makes women either maintain their speech style and represent it in fiction as it is or change it because they want to ascribe themselves and their written representations to a specific genre and a particular profession respectively.
\end{abstract}

"You're talking like a woman".

"You noticed".

"Why are you talking like a woman?"

"Because you're talking like a man? You come bounding in here, offering to give me a story, arranging a job for me as if I were someone who has to be taken care of, as if you, The Big He, are the source of The Power and The Glory Forever and Ever. Ah, men!"

(McDonald 1978: 238) 


\section{Introduction}

According to Kathleen Gregory Klein, "the predictable formula of detective fiction is based on a world whose sex/gender valuations reinforce male hegemony" and whose norm is male behaviour (1988: 223). Against this essentially masculine literary tradition, women writers such as Sue Grafton, Liza Cody or Sara Paretsky challenge and reformulate both the detective formula and gender norms and by placing a female detective at the centre of their fictional works engage "with both patriarchal language and the masculine hard-boiled tradition, appropriating [...] their formal strategies" (Walton \& Jones 1999: 148). The detective novel turns then into an extremely productive field of research with regard to the analysis of gender differences. Therefore, it is our intention in this article to study the represented speech of men and women in the specific genre of the detective novel.

It has been generally considered that represented speech deviates from real speech in a number of ways -namely, there are fewer interruptions, fewer incoherent and unfinished statements, fewer false starts and, in general, a substantial reduction of other linguistic devices typical of real speech (Carter et al., 1997: 286-295). However, as Burton asserts there is a very close relationship between the way characters speak inside novels and the way people do actually speak in the real world. It is for this reason that we have focused on analysing features of real conversation in represented literary dialogues. Accordingly, the research questions in the present study read as follows:

(1) Are the male/female stereotypes - "the trivial chattering, nagging woman" versus "the strong, silent, long-suffering man" (Carter et al 1997: 292) - reproduced in these fictional represented conversations?

(2) Do men and women appear to talk differently in the represented dialogues analysed?

(3) Do female detectives talk similarly to or differently from male detectives?

(4) Do female detectives talk differently from other females?

(5) Does the fact that the writer of a detective story is a man or a woman affect the way male and female speech is represented?

\section{Gender studies and represented speech}

\subsection{Genderised differences in language usage}

According to gender studies, male/female stereotypes have been taken for granted. As Carter et al (1997: 292) put it, "there were the trivial chattering, nagging woman" on the one hand, and "the strong, silent, long-suffering man", on the other hand. Needless to say, these were male generated stereotypes which suggested men's language habits as the appropriate use of language, whereas female language habits appeared as a distortion of the true purposes for which language had been devised. Gender studies research, however, has shown that these stereotypes are false. For instance, Kramer (1977) reported how studies 
both in Britain and the USA had shown that in many circumstances men talk more than women do.

Context seems to be central in the description of men's and women's differences in language usage (Tannen 1992; Coates 1993; Freed and Greenwood 1996). A pragmatic linguistic analytical framework allows researchers to determine where and when men and women do use language differently. However, sometimes, these differences, which do exist, have been over-emphasised. Thus, much complementary language analysis is needed in order to either verify or reconsider the linguistic features which have generally been assigned to women's speech, namely the use of questions, or tag questions, or the more frequent use of lexicalised expressions such as you know, among others.

\subsection{The relevance of context}

It is our contention that it is only taking context as a central issue that we can obtain a more accurate description of how men and women do differ in the use of language. This is a general trend in linguistics and stylistics. Haynes (1989) presents a five-level description of language from substance (level 1) and form (level 2), to discourse (level 3), context (level 4) and ideology (level 5) in order to unfold the distinct features of any text.

Similarly, Fairclough $(1992 ; 1995)$ has more recently presented a three-level description of language in order to interpret texts: he distinguishes between the textual level, the discursive level and the sociodiscursive level, where again, the concepts of context and ideology are key in any linguistic analysis. Fairclough's conceptual framework originates from discourse analysis. In fact, he comes to define his approach to the description of language usage as critical discourse analysis (CDA) (1995).

\subsection{Represented speech in fiction}

Substantial work has already been done in relation to gender differences in real speech (Bergvall 1999; Ehrlich 1999; Freed 1999; Meyerhoff 1999), but not so much research has been generated in relation to the representation of speech. In our understanding, this complementary research is especially necessary due to the general impact of certain genres which include represented speech forms and whose influence on society at large is enormous, namely, Hollywood films or best-selling novels.

Although there are a significant number of studies on the dialogic interaction in literature (Ohman 1971, 1973; van Dijk 1976; Pratt 1977), most of them deal with drama discourse (e. g. Fish 1976; Burton 1980; Elam 1981; Short 1981; Kennedy 1983; Gautam 1986, 1987; Nash 1989; Calvo 1991) and-to a certain extent-leave aside the study of the reproduction of conversational practice in novels. Nevertheless, and in spite of the relevance of plays, we encounter some studies on the analysis of dialogue in novels in general (e. g. Page 1973; Simpson 1983; Toolan 1985, 1987; Leech and Short 1995) and, most recently, in crime fiction in particular (Calvo 1995, Calvo \& Geluykens 1995). 
Most of the studies about fictional speech defend its conception as "represented dialogue", and consider that it "may aspire to a special kind of realism, a special kind of authenticity, in representing the kind of language which a reader can recognise, by observation, as being characteristic of a particular situation" (Leech \& Short 1995: 160). Toolan admits more overtly the limitations of reproducing conversation in fiction and states that "fictional dialogue is an artificial version of talk" (1988: 249). Moreover, for him "it would be a mistake to think of literary dialogue as a direct transcription of real speech" and he defends the idea that, if we insist on the latter consideration, we should speak of fictional dialogue as "a modulated or refracted transcription" (1988: 250). According to Toolan, fictional dialogue would be a "literary sub-register" (ibid) submitted to certain norms, i. e.: a literary convention. He lists several norms of dialogue rendering which are not usually observed in literature but that should be followed if a writer is to create a "realistic effect": he speaks of the need to use marks of speech overlaps and/or simultaneities, interruptions, hesitation, false starts, self and other-repairs, reformulations and similar linguistic features (ibid).

Much earlier, Leech and Short had solved Toolan's misgivings with regard to the literary representation of dialogue by claiming that "the author of a literary fiction does not aim at a completely realistic representation of the features of ordinary conversation" (1995 (1981): 163). For them, great writers do not aspire so much to realism, "as to a superior expressiveness of the kind we do not ordinarily achieve in real life" (1995 (1981): 166). As a consequence, fictional dialogue would result in a representation of talk governed by literary conventions "so that the rendered text is quite other than a faithful transcription of a natural conversation" (Toolan 1987: 195). However, and notwithstanding the artificiality of the dialogic interactions in fiction, it is our contention that the analysis of the speech of men and women detectives in this genre will offer a valuable insight into the study of language variations between genders.

The detective story, one of the most "American" of literary forms, provides one of the most interesting "character types" in literature, that of the "tough, hardboiled, individualistic, cynical, sometimes sneering, and always courageous hero" (Margolies 1982: 1). Emerging some time after World War I and flourishing throughout World War II, this popular genre has had, for a long time, as its main protagonist "a bachelor, individualistic, unswervingly honest, isolated and classless, who tends to regard most social and political institutions as soft or too amenable to corruption" (Margolies 1982:2). Carroll John Daly's Race Williams is the first of a series of celebrated tough private eyes among whom we encounter Dashiell Hammett's Sam Spade, Raymond Chandler's Philip Marlowe, Mickey Spillane's Mike Hammer, Chester Himes's brutal black cops, Coffin Ed Johnson and Grave Digger Jones, John MacDonald's Travis McGee and Ross MacDonald's Lew Archer (Margolies 1982).

Not until 1977 will the figure of a hard-boiled woman detective appear in a fictional work. Then, Marcia Muller's PI Sharon McCone, often heralded as "the founding mother of the contemporary female hard-boiled private eye" (Walton \& Jones 1999: 15), opens a new tendency within a typically genuine male domain. ${ }^{1}$ In fact, it is worth noticing how 
many of the critical notes about the detective hero even during the 1980 's still refer to this figure as "he", "a tough man" with no allusions at all to the figure of the woman detective (Geherin 1985). According to this author, the male protagonist of these stories chooses to tell "his own tale in language that is tough and hard-hitting, punctuated by colourful slang, irreverent wisecracks, rude wit and iconoclastic humor" (ibid. 199). Therefore, the detective novel offers invaluable grounds to analyse how the characteristic language of male detectives is used and/or modified by female detectives within the "Community of Practice" theoretical framework.

\section{Methodology}

\subsection{Corpus selection}

Conversations have been randomly selected from eight different novels written by four well-known and best-selling authors: two male authors (Gregory McDonald and Robert B. Parker), and two female authors (Patricia Cornwell and Sara Paretsky). The novels chosen are Fletch and Fletch 's Fortune by Gregory McDonald, God Save the Child and Small Vices by Robert B. Parker, Unnatural Exposure and The Body Farm by Patricia Cornwell and, finally, Bitter Medicine and Guardian Angel by Sara Paretsky, as they offer a wide range of dialogic interactions. Five conversations have been selected from each of these books ${ }^{2}$ (see tables 1a and 2a). The total number of dialogues amounts to 79 different represented one-to-one conversations divided into four groups: male detective $\mathrm{v}$. man; male detective v. woman; female detective v. man; female detective v. woman (see table $1 \mathrm{~b}$ and $2 \mathrm{~b}$ ).

All the dialogic interactions are one-to-one conversations between the main character in the novel, a detective, and another character. In the case of the novels written by a male author the main character is a male detective, whereas in the case of the female authors the main character is a female detective. Thus, in the case of each male writer we have two sets (one per novel) of male detective-to-man conversations on the one hand, and two sets (one per novel) of male detective-to-woman conversations, on the other hand; complementarily, in the case of each female writer, we have two sets (one per novel) of female detective-towoman conversations and two sets (one per novel) of female detective-to-man conversations (see tables 1a and $2 \mathrm{a}$ on next page).

This gives a total number of 19 male detective-man represented conversations, 20 male detective-woman conversations, 20 female detective-woman conversations, and 20 female detective-man conversations (see tables $1 b$ and $2 b$ ). The reason for presenting results in this manner is to analyse data taking into account gender differences.

\subsection{Linguistic variables analysed}

The linguistic variables which have been selected for study in this paper are: (i) the use of questions; (ii) the use of tags; (iii) the use of the hedge you know; and (iv) the use of well. 
TABLE 1a Corpus distribution of male writers' dialogues

\begin{tabular}{|c|c|c|c|c|}
\hline Writer's gender & writer & Novel & Type of dialogue & Number \\
\hline \multirow{8}{*}{ Male } & \multirow{4}{*}{ Parker } & \multirow[t]{2}{*}{ God save the Child } & Man detective-to-man & 5 \\
\hline & & & Man detective-to-woman & 5 \\
\hline & & \multirow{2}{*}{ Small Vices } & Man detective-to-man & 5 \\
\hline & & & Man detective-to-woman & 5 \\
\hline & \multirow{4}{*}{ MacDonald } & \multirow{2}{*}{ Flecth's Fortune } & Man detective-to-man & 4 \\
\hline & & & Man detective-to-woman & 5 \\
\hline & & \multirow{2}{*}{ Flecth } & Man detective-to-man & 5 \\
\hline & & & Man detective-to-woman & 5 \\
\hline
\end{tabular}

TABLE Ib. Corpus distribution: man detecive-fo-man and man detective-to-woman dialogues

\begin{tabular}{|l|c|c|}
\cline { 2 - 3 } \multicolumn{1}{c|}{} & Number of dialogues & Number of words \\
\hline Man detective-to-man dialogues & 19 & 17,700 \\
\hline Total & 20 & 19,795 \\
\hline
\end{tabular}

TABLE 2a Corpus distribution of female writers' dialogues

\begin{tabular}{|c|c|c|c|c|}
\hline Writer's gender & Writer & Novel & Type of dialogue & Number \\
\hline \multirow{8}{*}{ Female } & \multirow{4}{*}{ Cornwell } & \multirow{2}{*}{ The Body Farm } & Woman detective-to-woman & 5 \\
\hline & & & Woman detective-to-man & 5 \\
\hline & & \multirow{2}{*}{ Unnatural Exposure } & Woman detective-10-woman & 5 \\
\hline & & & Woman detective-to-man & 5 \\
\hline & \multirow{4}{*}{ P'aretsky } & \multirow{2}{*}{ Bitter Medicine } & Woman detective-to-woman & 5 \\
\hline & & & Woman detoctive-to-man & 5 \\
\hline & & \multirow[t]{2}{*}{ Guardian Angel } & Woman detective-to-woman & 5 \\
\hline & & & Woman detective-to-man & 5 \\
\hline
\end{tabular}

TABLE 2b. Corpus distribution: woman detective-to-woman and woman detective-to-man dialogues

\begin{tabular}{|l|c|c|}
\cline { 2 - 3 } \multicolumn{1}{c|}{} & Number of dialogues & Number of words \\
\hline Woman detective-to-woman dialogucs & 20 & 21,317 \\
\hline Toman detoctive-to-man dialogues & 20 & 20,485 \\
\hline & 40 & 41802 \\
\hline
\end{tabular}


These variables have been selected because all of them have been previously analysed in gender studies focused on detecting significant differences between men's and women's speech (Dubois 1975; Brower 1979; Holmes 1984; Coates 1993).

\section{Gender differences in the represented speech of detectives}

Lakoff (1975) claimed that questions in general and tags in particular, as well as hedges such as you know were representative characteristics of women's speech. Since then, many studies have endeavoured to clarify this issue (Dubois and Crouch 1975; Brouwer et al. 1979; Fishman 1980; Holmes 1984; Coates 1996). Nevertheless, most of these studies have been challenged. A considerable amount of research on assymmetrical discourse (i. e. magistrate-defendant (Harris 1984), doctor-patient (West 1984) or teacher-pupil (Stubbs 1983)) defends that questions are overwhelmingly used by powerful participants. According to this, it would be the occupational status and not the gender the variable which determines the use of questions (Coates 1993).

Our study shows how, contrary to what has been generally accepted (e. g. Lakoff 1975), within this corpus of represented dialogues women make a smaller use of questions than men in their interaction with members of the same and the opposite sex, at least (see table 3).

TABLE 3. Use of questions across genders

\begin{tabular}{|l|c|c|}
\cline { 2 - 3 } \multicolumn{1}{c|}{} & \multicolumn{2}{c|}{ Questions } \\
\cline { 2 - 3 } \multicolumn{1}{c|}{} & $\mathrm{N}$ & $\%$ \\
\hline Men detectives + other men & 740 & 56.15 \\
\hline Women detectives + other women & 578 & 43.85 \\
\hline
\end{tabular}

But not only that: it is interesting to remark that not even when a woman adopts the role of leading detective do her questions outnumber those of her male interlocutors (see table 4).

TABLE 4. Use of questions, tags, well and you know across the different types of dialogues in the corpus

\begin{tabular}{|l|c|c|c|c|c|c|c|c|}
\cline { 2 - 9 } \multicolumn{1}{c|}{} & \multicolumn{2}{c|}{ Man detective-to-man } & Man detective-to-woman & Woman detective-to-woman & \multicolumn{2}{c|}{ Woman delective-to-man } \\
\cline { 2 - 10 } & $\begin{array}{c}\text { Man } \\
\text { detective }\end{array}$ & Other men & $\begin{array}{c}\text { Man } \\
\text { defective }\end{array}$ & Women & $\begin{array}{c}\text { Woman } \\
\text { detective }\end{array}$ & $\begin{array}{c}\text { Other } \\
\text { women }\end{array}$ & $\begin{array}{c}\text { Woman } \\
\text { detective }\end{array}$ & men \\
\hline N of questions & 176 & 188 & 250 & 230 & 126 & 119 & 103 & 126 \\
\hline N of tags & 3 & 4 & 4 & 5 & 0 & 10 & 4 & 6 \\
\hline N of Well & 3 & 15 & 7 & 9 & 5 & 12 & 6 & 6 \\
\hline N of you knows & 3 & 32 & 5 & 12 & 2 & 5 & 5 & 5 \\
\hline N of words & \multicolumn{3}{|c|}{17,700} & \multicolumn{2}{|c|}{19,795} & & 21,317 & 20,485 \\
\hline
\end{tabular}

Example (1) illustrates this situation. The extract is also a good instance of some of Tannen's differences between male and female distinct conversational styles. In (1), the man systematically leads the topic of the interaction mostly through his questions and gets to the point of directly interrupting the female detective (see underlined section in the text). 
Both topic-raising and interruption have been pinpointed as typical of male conversational style by Tannen (1992).

(1) "What the hell is it now?" he said right off.

$[\ldots]^{3}$

"Come on," I [ = female detective $]$ said.

$[\ldots]$

"Is this what the shit I think it is?" he said.

"Appears the photograph was taken where the body was dismembered". [...]

"This is what you found today".

"What you're looking at was taken shortly after death, "I said. "But yes, this is the torso from the landfill".

"How do you know?" Marino said.

$[\ldots]$

"I have things where I want them, " $[\ldots]$

"Hey, chill out, Doc," he said as if it didn't matter. "How do we know that this thing ain't a hoax?"

$[\ldots]$

"Marino, you're going to have to get up," I said. "I don't let anybody sit at my desk. You're making me crazy".

He shot me an angry look and got up out of my chair. "Hey, do me a favor. Next time call somebody else when you got a problem".

"Try to be sensitive. . ".

He cut me off, losing his temper. "No. You be sensitive and quit being such a friggin' fussbudget. No wonder you and Wesley got problems".

"Marino," I warned, "you just crossed a line and better stop right there".

[...]

"Let's get back to this". I sat in my chair, readjusting it. "I don't think this is a hoax, and I believe it's the torso from the landfill".

"Why?" He would not look at me, hands in his pockets.

"Arms and legs are severed through the long bones, not the joints". I touched the screen. "There are other similarities. It's her, unless another victim with a similar body type has been killed and dismembered in the same manner, and we've not found her yet. And I don't know how someone could have perpetrated a hoax like this without knowing how the victim was dismembered. Not to mention, this case hasn't hit the news yet".

"Shit". His face was deep red. "So, is there something like a return address?"

"Yes. Someone on AOL with the name D-E-A-D-O-C".

"As in Dead-Doc?" He was intrigued enough to forget his mood.

"I can only assume. The message was one word: ten".

"That's it?".

"In lowercase letters".

He looked at me, thinking. "You count the ones in Ireland, this is number ten. You got a copy of this thing?"

"Yes. And the Dubiin cases and their possible connection to the first four here have been in the news". I handed him a printout. "Anybody could know about it". 
"Don't matter. Assuming this is the same killer and he's just struck again, he knows damn well how many he's killed," he said. "But what l'm not getting is how he knew where to send this file to you?" (Cornwell 1997: 26-7).

As example (1) above illustrates, we feel that it may be stated that questions are not characteristic of women's represented talk in these fictional dialogues.

If we are to accept questions as instruments of power, the use of interrogative instances asked by the leading man/woman detectives would be a dominant feature in the different novels. However, figures seem to disregard also our initial intuitions about the pre-eminent use of questions by the leading man/woman detectives in the different novels. The data show how, in the leading detectives' interaction with other characters, the former are outnumbered in their use of questions by their interlocutors (see table 5).

TABLE 5. Use of questions in the leading-detective profession (Comparing the main characters in each novel, i.e. the leading detective profession, with the rest of male and female characters)

\begin{tabular}{|l|c|c|}
\cline { 2 - 3 } \multicolumn{1}{c|}{} & \multicolumn{2}{c|}{ Questions } \\
\cline { 2 - 3 } \multicolumn{1}{c|}{} & $\mathrm{N}$ & $\%$ \\
\hline Leading detective CofP & 555 & 47.57 \\
\hline Rest of characters & 663 & 54.43 \\
\hline
\end{tabular}

The following example shows this different usage of questions between the leading detective and another character. Notice that both are of the same gender (in this case, females):

(2) "Aunt Kay, what's your password in AOL?" she [= female character] asked.

"The same one I use for everything else, " I [ =female detective] confessed, knowing she would be annoyed again.

"Shit. Don't tell me you're still using Sinbad". She looked up at me.

"My mother's rotten cat has never been mentioned in anything ever written-about me," I defended myself.

I watched as she typed the command password and entered Sinbad.

"Do you do password aging?" she asked as if everyone should know what that meant.

"I have no idea what you're talking about".

"Where you change your password at least once a month".

"No," I said.

"Who else knows your password?" (Cornwell 1997: 75).

Nevertheless, this could be explained by the fact that frequently the latter also belongs to the detective community and, consequently, we are dealing with two investigators engaged in a dialogic interaction. This is exactly the case in example (3) below:

(3) "What's your name? [=male Police Inspector $]$

"Fletch" [=male detective] 


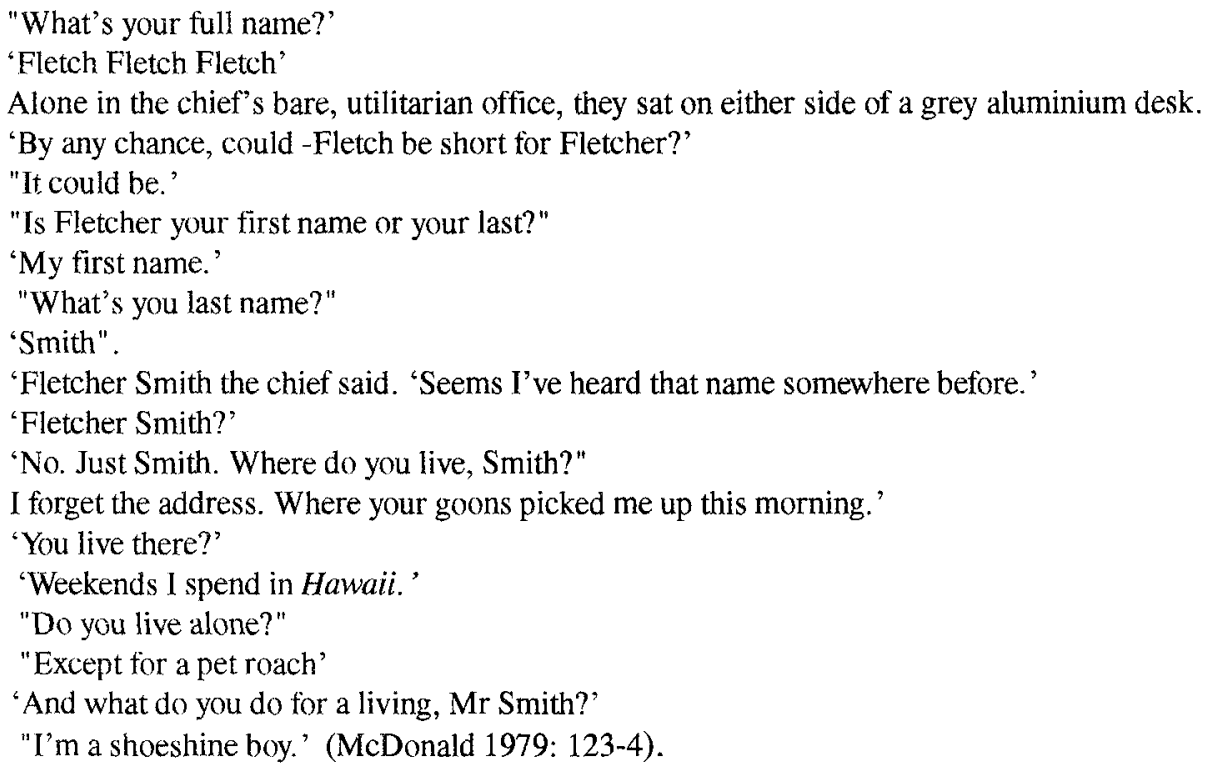

Still, we do believe questions are a representative feature of detectives, since, as we said above, when the other interlocutors also ask many questions they too-in most cases-belong to the same profession. This fact would be related to recent studies in discourse analysis which have suggested that "questions are in fact potentially powerful linguistic forms" (Coates 1996: 200) and contradicts Lakoff's claim that questions are typical of women and are "an expression of tentativeness" (1975: 17). However, the only way to check that statement would be to count the number of questions in a similar set of represented dialogues in a novel of a different genre (namely, love, mystery, or sciencefiction to mention some).

Tags have also been treated as an archetypal woman's form (Lakoff 1975; Holmes 1984, Coates 1996). In this case, however, contrarily to what happened with questions, the data obtained in our analysis do confirm tags as a feature representative of female talk (see table 4). Nevertheless, and although, generally speaking, women used more tags than men in our corpus, it is interesting to notice that when dealing with female investigators, the number of tags lessens. This is easily explained, if we apply Holmes' model of analysis (1984). She distinguishes between tags which express either modal or affective meaning. Tags with modal meaning signal the speaker's degree of certainty about the proposition expressed and can be described as speaker-oriented whereas tags with affective meaning express the speaker's attitude to the addressee and are, consequently, addressee-oriented (Coates 1996: 120). According to our results (see table 6), tags with modal meaning are very common among men whereas tags with affective meaning are more frequent among women (Holmes 1984). 
TABLE 6. Use of tag questions among female/male characters and female/male leading detectives

\begin{tabular}{|c|c|c|c|c|}
\hline Type of meaning & female & male & Fernale detective & Male detective \\
\hline Modal meaning & 1 & 9 & 4 & 7 \\
\hline Affective meaning & 14 & 1 & -- & -- \\
\hline
\end{tabular}

These data are relevant as they reflect the typical roles assigned to men and women in conversation-i.e. rapporting for women and reporting for men (Tannen 1992). In other words, whereas women are more likely to develop emotional links in conversation through their use of tags, men tend to use them in order to confirm their certainties. Detectives' use of tag questions with modal meaning is clearly determined by their needs and the reduced number of tag questions present in women detective interactions responds to their need of approaching the male detective's speech mode in order to reassert themselves as members of the profession.

It also has to be noted that the use of of tags, you know, and well, is very similar in number when the dialogic interaction takes place between members of the opposite sex, whereas the exchange between members of the same sex is characterized by greater numerical differences ${ }^{4}$ (see table 4). This leads us to assert that men and women use these features similarly and that differences in the use of these linguistic devices could be related to a specific professional group.

In general, we can find a more widespread use of tags, well, and you know among men or women not belonging to the detective profession. Moreover, it seems that these elements become distinctive features of some of the characters being questioned by men or women detectives. For example, in (4), a bitter conversational exchange which takes place between V. I. Warshawski, the woman detective in the novel, and Mrs. Marcano, her protective neighbour's daughter, tag questions become the latter's identity traits:

(4) So you're the lady that got him into so much trouble. 1 might've guessed. He got his head cut open for you two weeks ago, didn't he? But that wasn't enough, was it? You had to try to get him killed, too, didn't you? (Paretsky 1987: 137-8).

Similarly, in (5), Mrs Amelia Shurcliffe, the Society Editor Fletch interacts with, epitomizes the paradigm of a speech characterized by a relevant presence of you knows and wells:

(5) "Well, darling " [...] "All Brummel did, you know, was to bring the lean, simple country style into the city. '[...]"Well, I suppose someone had to marry her, of course. [...] You see them together at parties, Joan and her father - you know, benefits for cancer, or muscular dystrophy, or some of his other charities - [...] "Well, her husband, Alan Stanwyk, is running an enormous company, and at an early age" (McDonald 1979: 45-9). 
If we now revise our initial research questions it is possible to provide answers to each of them, even though in several instances further research would be necessary to confirm our hypotheses. First of all, we believe that male/female stereotypes are not reproduced in these fictional represented conversations, especially when it comes to female writers who endeavour to incorporate their protagonists into a typically male role. A relevant area for further research would be to increase the number of male and female writers and compare the way their respective male and female characters use language in conversations.

Secondly, men and women do talk differently but in contradiction with stereotypes; for instance, women ask fewer questions than men. Complementarily to this finding, the data obtained in this study also suggest that other differences in the conversational devices analysed are more easily related to the speaker's/character's profession rather than to their gender, or to distinct conversational styles. This would be the case in the use of affective versus modal tags.

Thirdly, in relation to whether female detectives talk similarly to or differently from male detectives, here the data are contradictory. For instance, female detectives ask fewer questions when facing other male characters, whereas male detectives ask more questions when talking to female characters, but both male and female detectives seem to use tags similarly. Data suggest that female detectives are getting closer to using language as their male counterparts do but they are not quite using it in the same way yet.

In general, questions could be a characteristic of detectives. However, further research is needed to confirm this assertion. On the other hand, the systematic avoidance of tags with affective meaning does seem a characteristic feature in the speech of the represented detective profession. Also, female detectives do talk differently from other females: women detectives in general use fewer affective tags, wells and you knows than the rest of female characters, in accordance with their effort to enter the detective community; in relation to the use of questions, differences are not so distinct. And finally, the writer's gender also influences, up to a certain extent, the representation of detective talk: male detectives use fewer questions when talking to other men in male written novels than when interrogating women. Nevertheless, and despite women's efforts to fight their way into the detective writer "exclusive club", female detectives in female written novels, only ask more questions when talking to other women.

\section{Conclusions}

On the one hand, it seems that genre style-the detective novel-tends to eliminate gender differences because female writers intend to introduce their leading female detective characters into the typically male domain of the detective profession. Nevertheless, women writers' attempts to give their women detectives an equal status to that of men detectives is not completely successful yet. For instance, we can observe how female detectives still ask fewer questions than their male counterparts. On the other hand, the woman's struggle to enter the detective community runs parallel to and can be explained by her female creator's 
efforts to find her place in this traditionally considered male domain and the rigid social constraints which tie her to a more conservative use of the linguistic conversational devices characteristic of the professional group she wishes to portray.

Although this paper is of limited scope and further empirical work is needed in order to draw firm conclusions, we hope to have shown that notwithstanding the differences in men's and women's talk, these differences do not always take place in all situations. As some recent gender studies have displayed (Bucholtz 1999; Ehrlich 1999) the women's struggle to justify their belonging to a specific profession leads them to reproduce the speech style generally acknowledged by the established group. But that this is so does not change Tannen's (1992) and Coates' (1993) and other linguists' theories on different male/female speech styles. We believe it is the context, the pragmatic situation which makes women either maintain their speech style and represent it in fiction as it is or change it because they want to ascribe themselves and their written representations to a specific genre and a particular profession respectively.

\section{Notes}

1. The first American incarnation of the hard-boiled female private eye was Maxine O'Callaghan's Delilah West. She was the protagonist of a short story published in Alfred Hitchkock Magazine in November 1974 and her appearance was, nevertheless, "an event little noted by the world, simply because the world wasn't yet ready for the fictional female private investigator" (Muller 1994: 9) (Walton \& Jones 1999: 18). Walton \& Jones give a very elaborate account of the appearance and evolution of female detective fiction (1999: 10-43).

2. With the exception of Fletch's Fortune because only four conversations have been taken down from this novel due to the impossibility to obtain more one-to-one dialogues in this book. Although there is one conversation less in this group, the four groups of conversations in the corpus are made up of a similar number of words. See tables $1 b$ and $2 b$.

3 . We have deleted narrative stretches in order to highlight dialogic interaction.

4. It has to be noted that especially in relation to the use of tags, you knows and wells, there are fewer items than in real conversations, due to the fact that these are typical features of spoken discourse/speech and what we are dealing with here is with its written fictional representation.

\section{Works cited}

Bergvall, Victoria (1999): "Toward a comprehensive theory of language and gender". Language in Society: 28: 273-293.

Bucholtz, Mary (1999): "'Why be normal?': Language and identity practices in a community of nerd girls". Language in society 28: 203-223.

Burton, Deirdre (1980): Dialogue and Discourse: A Sociolinguistic Approach to Modern Drama and Naturally Occurring Conversation. London: Routledge.

Calvo, Clara (1991): Power Relations and Fool-Master Discourse in Shakespeare. A Discourse Stylistics Approach to Dramatic Dialogue. Monographs in Systemics Linguistics. N. 3. Nottingham: Department of English Studies. 
Calvo, Clara (1995): "Telephone conversation in the fiction of Raymond Chandler: opening up openings and closings". In Angela Downing, ed., Estudios Ingleses de la Universidad Complutense 3. Madrid: Servicio de Publicaciones de la Universidad Complutense.

Calvo, Clara and Ronald Geluykens (1995): "Politeness strategies and sequential organization in crime fiction telephone conversations" Interface-Journal of Applied Linguistics, 9(2): 49-66.

Carter, Ronald and Simpson Paul (eds.)(1989): Language, Discourse and Literature. London: Unwin Hyman.

Carter, Ronald et al. (1997): Working with Texts: A core book for language analysis. London: Routledge.

Coates, Jennifer (1996): Women Talk. Oxford: Blackwell Publishers.

Ehrlich, Susan (1999): Communities of practice, gender, and the representation of sexual assault. Language in Society 28: 239-256.

Elam, Keir (1981): The Semiotics of Theatre and Drama. London: Methuen.

Fairclough, Norman (1992): Discourse and Social Change. Cambridge: Polity Press/Blackwell Publishers.

. (1995): Critical Discourse Analysis. London: Longman.

Fish, Stanley (1976): "How to Do Things with Austin and Searle: Speech Act Theory and Literary Criticism". Modern Language Notes 91: 983-1025.

Freed, Alice (1999): "Communities of practice and pregnant women: Is there a connection?". Language in Society 28: 257-271.

Gautam, Kripa K. and Manjula Sharma (1986): "Dialogue in Waiting for Godot and Grice's concept of implicature" Modern Drama 29(4): 580-586.

Gautam, Kripa (1987): "Pinter's The Caretaker: A Study in Conversational Analysis". Journal of Pragmatics 11(1): 49-59.

Geherin, David (1985): The American Private Eye. The Image in Fiction. New York: Frederick Ungar.

Harris, Sandra (1984): "Questions as a Mode of Control in Magistrates' Courts", International Journal of the Sociology of Language 49.

Haynes, John (1989): Introducing Stylistics. London: Routledge.

Holmes, Janet (1984): "Hedging your Bets and Sitting on the Fence: Some Evidence for Hedges as Support Structures", Te Reo, 27: 47-62.

Kennedy, Andrew K. (1983): Dramatic Dialogue: The Duologue of Personal Encounter. Cambridge: CUP.

Kramer, C. (1977): "Perceptions of male and female speech". Language and Speech, 20: 151-61. Lakoff, Robin (1975): Language and Woman's Place. New York: Harper \& Row.

Meyerhoff, Miriam (1999): "Sorry in the Pacific: defining communities, defining practices". Language in Society, 28: 225-238.

Nash, Walter (1989): "Changing the Guard at Elsinore". In Ronald Carter and Paul Simpson, eds., Language, Discourse and Literature. London: Unwin Hyman, 23-41.

Ohmann, Richard (1971): "Speech Acts and the Definition of Literature". Philosophy and Rhetoric 4: $1-19$.

(1973): "Speech, Literature and the Space Between" New Literary History 4: 47-63.

Page, Norman (1973): Speech in the English Novel. London: Longman.

Pratt, Mary Louise (1977): Toward a Speech Act Theory of Literary Discourse. Bloomington: Indiana University Press. 
Short, Mike (1981): "Discourse Analysis and the Analysis of Drama". Applied Linguistics 2(2): 180-202. Reprinted in Ronald Carter and Paul Simpson, eds., 1989, 139-168.

Simpson, Paul (1989): "Phatic Communion and Fictional Dialogue". Reprinted in Ronald Carter and Paul Simpson, eds., 1989, 43-56.

Stubbs, Michael (1983): Discourse Analysis. Oxford: Basil Blackwell.

Tannen, Deborah (1992): You Just Don't Understand: Men and Women in Conversation. London: Virago.

Toolan, Michael (1985): "Analysing Fictional Dialogue". Language and Communication 5/3: 193-206.

. (1987): "Analysing Conversation in Fiction: an Example from Joyce's Portrait". Reprinted in Ronald Carter and Paul Simpson, eds., 1989, 195-211.

. (1988): "Compromising Positions: Systemic Linguistics and the Locally Managed Semiotics of Dialogue". In David Birch and Richard O'Toole, eds., Functions of Style. London: Pinter Publishers.

West, Candace (1984): Routine Complications: Troubles with Talk between Doctors and Patients. Indiana: Indiana University Press.

\section{Appendix: Nowels analysed}

Cornwell, Patricia (1994): The Body Farm. New York: Scribners. . (1997): Unnatural Exposure. New York: G. P. Putnam's sons.

McDonald, Gregory (1974): Fletch. London: Cox \& Wyman, 1979. . (1978): Fletch's Fortune. New York: Avon Printing.

Paretsky, Sara (1987): Bitter Medicine. New York: William Morrow. . (1987): Guardian Angel. New York: Dell Publishing.

Parker, Robert B. (1974): God Save the Child. Boston: Houghton Mifflin. .. (1997): Small Vices. New York: Berkley Books, 1998. 